\title{
(i) \\ Front Stress Distribution Under the Impact of Cutting Height to Caving Height Ratio in Extra- -thick Longwall Top Coal Caving Technology
}

\author{
Bui MANH TUNG ${ }^{1, *}$, Nguyen VAN QUANG ${ }^{1)}$, Nguyen PHI HUNG ${ }^{1)}$, \\ Vo NGOC DUNG ${ }^{2}$, Do HOANG HIEP ${ }^{3)}$
}

\footnotetext{
1) Department of Underground Mining, Hanoi University of Mining and Geology, Hanoi, Vietnam; email: buimanhtung@humg.edu.vn; nguyenvanquang@humg.edu.vn; nguyenphihung@humg.edu.vn

2) Department of Mine Surveying, Hanoi University of Mining and Geology, Hanoi, Vietnam; email: vongocdung@humg.edu.vn

3) Dong Bac Corporation, Ministry of National Defence, Quang Ninh, Vietnam; dohoanghiep3281@gmail.com
}

http://doi.org/10.29227/IM-2020-02-16

Submission date: 06-03-2020 | Review date: 22-09-2020

\section{Abstract}

The extraction with higher cutting height for extra-thick seam is the new research orientation in longwall caving technology. Due to the increase of top coal thickness and of cutting height which leads to the change of cutting/caving height ratio, the rule of roof failure (including top coal caving) and the distribution of stress around the face alter correspondingly. This paper is based on the geological conditions of face 8102 of Tashan-DaTong mine, employing the numerical model by UDEC2D code, analysing the effect of cutting/ caving height ratio on the law of stress distribution ahead of the face. When the ratio of cutting/caving height decreases and the cutting height increases, the results of the research have shown that: (i)-peak stress redistributes further ahead of the face and its value manifestly drops; (ii)- the plastic deformation ahead of face significant increases and the zone of plastic strain also expands. It is therefore concluded that the variation of cutting/caving height ratio results in the redistribution of roof pressure, which contributes to the control of roof failure and face stability.

Keywords: extra-thick seam, extra-cutting height, cutting/caving height ratio, stress distribution

\section{Introduction}

Fully mechanized longwall top coal caving is one of the technologies applying for extraction of thick coal seams in developed coal industries in the world. One limitation of this technology raised from practice is that coal loss during top coal caving process remains large. The extraction with higher cutting height for extra-thick seam is being the new research orientation in longwall caving technology. Due to the increase of top coal thickness and of cutting height which leads to the change of cutting-caving height ratio, the rule of roof failure (including top coal caving) and the distribution of stress around the face alter correspondingly.

The extraction of longwall top coal caving from the initially geological condition to the caving stage can be divided into two stages of the fracturing process and flowing/caving process. The effective fracturing of top coal is crucially beneficial to the caving, which is mainly dominated by the stress distribution in surrounding rock mass. Hence, the study on the capability of top coal should be based on the rule of stress distribution around the longwall. Many studies from Vietnam and in the world have used theoretical, physical and numerical modelling methods, observation methods to study the stresses around at LTTC face. For example, [N.E. Yasitli et al. 2005] applied 3D numerical modelling to longwall mining with top - coal caving. The study showed that maximum vertical abutment stresses were formed at a distance of $7 \mathrm{~m}$ in front of the face. An analysis of the conditions of top coal has revealed that a $1.5 \mathrm{~m}$ thick layer of coal just above the shield supports is well fractured. However, a $3.5 \mathrm{~m}$ thick layer of coal above the fractured part is either not fractured or is fractured in the form of large blocks leading to obstruction of windows of shields during coal drawing. [Wang jiachen, 2005, Humphries et al. 2007] found that the caving mechanisms and drawing of the loose top-coal are the keys to increase the recovery rate of top-coal. [G.S.P Singh et al., 2009] used numerical modelling approach for predicting the progressive caving behaviour of strata and performance of powered roof support in a given geo-mining and strata condition. The study suggested that face convergence slope of $75 \mathrm{~mm} / \mathrm{m}$ of face advance may be considered as the maximum permissible value for selection of optimal capacity support for safe working in a given strata condition. [Huang Bingxiang et al., 2011] researched rational cutting height for large cutting height fully mechanized top coal caving. The author showed that increased machine cutting heights of large cutting height fully mechanized top-coal caving reduces the thickness of the top-coal. Increased cutting height makes the ratio of cutting to drawing height change and caving change as well. But there is an optimum ratio of cutting to drawing height that maximizes the recovery ratio of the face. In [Jiachen Wang, et al., 2014], the mechanisms of the top-coal caving were examined by a large number of physical simulation experiments and numerical modelling of actual cases. A new research system for caving mechanism analysis was developed, and its application to sublevel topcoal caving mining was demonstrated in [Jiachen Wang et al., 2016). The author introduced a Boundary-Body-Ratio (BBR) research system following a

long-term detailed study of the top-coal drawing mechanism. The results show that the boundary curve of top-coal can be fitted by a parabola and that the drawing body remains 


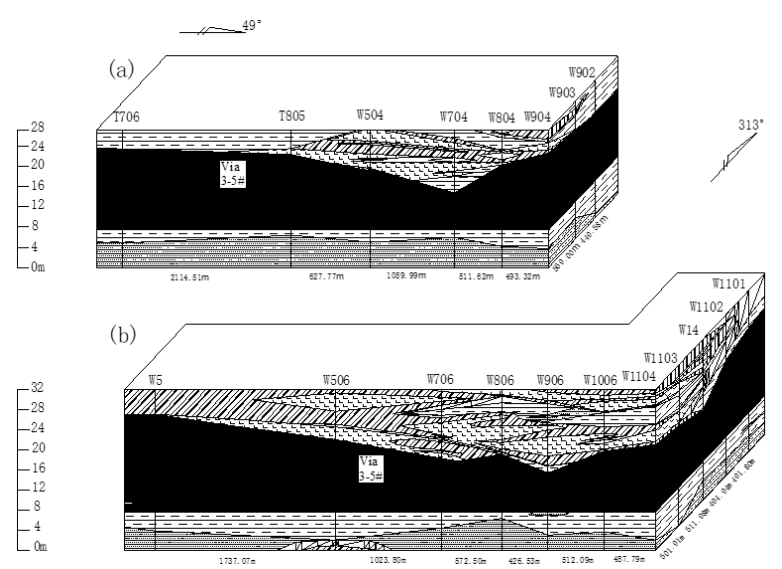

Fig. 1. Stratigraphic column of seam 3-5 in Tashan mine Rys. 1. Kolumna stratygraficzna pokładu 3-5 kopalni Taszan

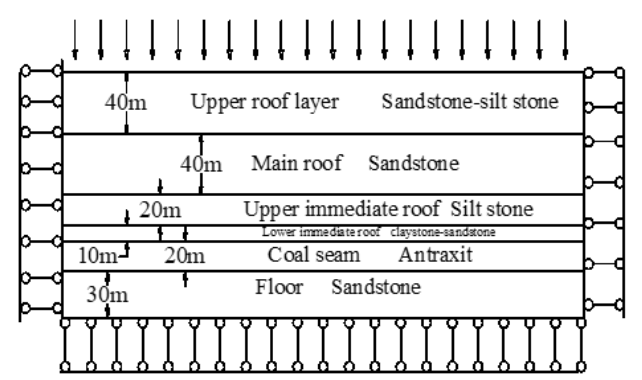

Fig. 2. Frame of Model

Rys. 2. Rama modelu

as a cut variation ellipsoid in a case for flat coal seam. [Le et al., 2018] studied the roof strata movement patterns under the specific conditions of a thick coal seam under a hard main roof. However, there have been no results to study the effect of the top-coal recovery ratio on the pressure in front of the longwall face.

This paper is based on the geological conditions of face 8102 of Tashan-DaTong mine, employing the numerical model by UDEC2D code, analyzing the effect of cutting-caving height ratio on the law of stress distribution ahead of the face. It is therefore concluded that the variation of cutting-caving height ratio results in the redistribution of roof pressure which contributes to the control of roof failure and face stability.

\section{Geological condition of mine}

The 8102 coalface exploited is in seams $3 \sim 5$ \#, varies in thickness from 12.63 to $29.20 \mathrm{~m}$, on average of $20 \mathrm{~m}$. The seam has a comparative complex structure with high cleavage and a single rock band of $0.6 \mathrm{~m}$ thickness. The rock mass is mainly composed of kaolin stone, kaolin-claystone, claystone-sandstone. Systems of joint relatively develop in the seam. Seam has moderate strength from $27 \mathrm{MPa}$ to $37 \mathrm{MPa}$, on average of $32 \mathrm{MPa}$. The spacing between the joints is from $15 \mathrm{~cm}$ to $25 \mathrm{~cm}$. The distance between the main joints is from $1.0 \mathrm{~m}$ to $1.2 \mathrm{~m}$. Joint angle is $55^{\circ}$. Coal is brittle and easy to be crushed.

The immediate roof rock mass is the metamorphic kaolin, schist and penetrated-igneous rock. The thickness of the immediate roof is uniform from $2 \mathrm{~m}$ to $8 \mathrm{~m}$. The strength of igneous rock is of grade IV in Protodiakonov classification. The stratigraphic column is shown in Figure 1.
3. Law of stress distribution ahead of a face when the cutting to caving height ratio changes

To study the effect of cutting/caving height ratio on the stress distribution law ahead of face, the numerical modelling UDEC2D code is employed for the simulation and analysis.

\subsection{Model generation}

The model is based on the geological data of face 8102 , TaShan Datong mine. The depth is from $300 \mathrm{~m}$ to $500 \mathrm{~m}$. The average thickness is $20 \mathrm{~m}$. The seam dip angle is stable from 2 to 10 degree, on average of 6 degree. The rock mass is highly jointed. The geomechanical properties of rock mass and joints are shown in Table 1, 2 .

In the model, the $\mathrm{X}$-axis represents the strike while the Y-axis is the vertical one. The length of model is $400 \mathrm{~m}$; the height is $160 \mathrm{~m}$; the depth of mining is $450 \mathrm{~m}$; thickness of seam is $20 \mathrm{~m}$. The framework of model is outlined in Figure 2. The models are built up with the ratio of cutting/caving height being 1:4.55 (cutting height $3.6 \mathrm{~m}, 1: 3$ (cutting height $5.0 \mathrm{~m}$ and 1:2.08 (cutting height $6.5 \mathrm{~m}$ respectively.

\subsection{Analysis of Result}

The rotation of the main roof and the compression of the entire main roof are the major factors affecting the breakage of roof rock and top coal. The zone adjacent to the face is called the balanced-abutment stress zone. The bordering point between this zone and the elastic deformation zone is called the peak abutment stress. The stress distributing ahead of the face is divided into decreasing stress zone, increasing stress zone and the primary stress zone. Figure 3 and Figure 4 show the stress distribution in front the face during and af- 
Tab 1. Material properties of model

Tab. 1. Właściwości materiałów modelu

\begin{tabular}{|l|c|c|c|c|c|c|}
\hline \multicolumn{1}{|c|}{ Layers } & $\begin{array}{c}\text { Density } \\
\mathbf{d} / \mathbf{N} \cdot \mathbf{m}-\mathbf{3}\end{array}$ & $\begin{array}{c}\text { Shear } \\
\text { modulus } \\
(\mathbf{K}) \mathbf{G p a}\end{array}$ & $\begin{array}{c}\text { Bulk } \\
\text { modulus } \\
(\mathbf{G}) \mathbf{G p a}\end{array}$ & $\begin{array}{c}\text { Cohesion } \\
(\mathbf{C}) \mathbf{M p a}\end{array}$ & $\begin{array}{c}\text { Internal } \\
\text { friction f/ }\end{array}$ & $\begin{array}{c}\text { Tensile strength } \\
\mathbf{t} / \mathbf{M p a}\end{array}$ \\
\hline Main roof & 2500 & 25 & 18 & 4 & 45 & 2 \\
\hline Upper immediate roof & 2500 & 17.5 & 10 & 2 & 38 & 1.3 \\
\hline Lower immediate roof & 2500 & 12 & 3 & 1.4 & 35 & 0.93 \\
\hline Coal seam & 1400 & 3.2 & 1.2 & 1 & 33 & 0.3 \\
\hline Immediate floor & 2679 & 12 & 3 & 1.4 & 35.8 & 0.93 \\
\hline
\end{tabular}

Tab. 2. Joints properties of Model

Tab. 2. Właściwości warstw modelu

\begin{tabular}{|l|c|c|c|c|c|}
\hline \multicolumn{1}{|c|}{ Layers } & $\begin{array}{c}\text { Normal stiffness } \\
(\mathbf{j k n}) \mathbf{G p a}\end{array}$ & $\begin{array}{c}\text { Shear stiffness } \\
\text { (jks) Gpa }\end{array}$ & $\begin{array}{c}\text { Cohesion } \\
\text { (joh) Mpa }\end{array}$ & $\begin{array}{c}\text { Internal friction } \\
\text { Jfric } /{ }^{\circ}\end{array}$ & $\begin{array}{c}\text { Tensile strength } \\
\text { (jten) Mpa }\end{array}$ \\
\hline Main roof & 11 & 7 & 0.08 & 35 & 0.05 \\
\hline Upper immediate roof & 9 & 6 & 0.06 & 32 & 0.04 \\
\hline Lower immediate roof & 7 & 4.5 & 0 & 0 & 0 \\
\hline Coal seam & 5 & 3 & 0.04 & 15 & 0.02 \\
\hline Immediate floor & 7 & 4.5 & 0.04 & 15 & 0.04 \\
\hline
\end{tabular}
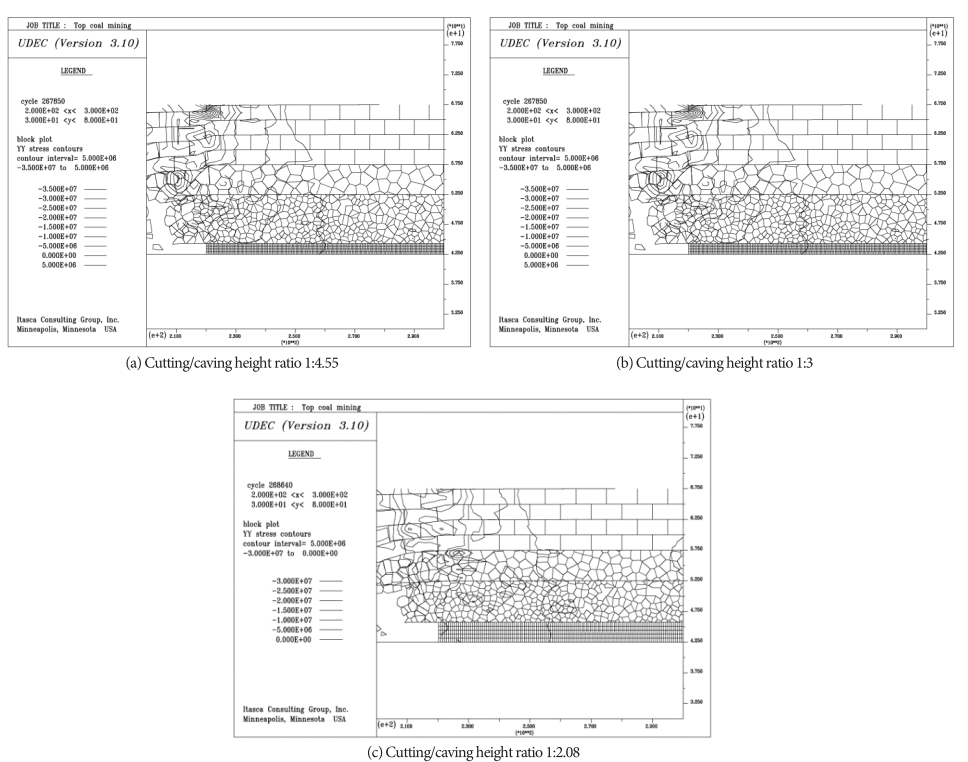

Fig. 3. Stress distribution in front of the face during the appearance of periodic pressure

Rys. 3. Rozkład naprężeń przed ścianą podczas pojawienia się okresowego ciśnienia

ter the appearance of periodic stress when the cutting/caving height ratios are 1:4.55, 1:3, and 1:2.08.

The analysis of modelling shows that during the appearance of periodic pressure and subject to the decrease of cutting/caving ratio: the plastic deformation is greatly damaged; the ability of top coal to resist the failure falls down; the increasing stress area expands and moves further from the coal face, leading failure zone of top coal to develop. This is beneficial to the failure of top coal which is broken mainly due to the rotary effect of a main roof rock mass.

After the appearance of periodic pressure, the model indicates that subject to the decrease of cutting/caving ratio: the increasing stress area moves from the top to the adjacent face zone; the increasing stress area dwindles and moves to the contiguous zone of shearer zone. At this moment, the failure of top coal is mainly controlled by the compression of the entire main roof rock.

From the above analyses, it can be seen that when the cutting/caving ratio decreases which means the cutting height is rising and top coal thickness thinning, the activities lev- el of the main roof rises, leading to the stress redistribution at top coal as well as widening the plastic deformation zone, improving the destruction process of top coal. However, the stability of face declines.

To deeper analyze the stress distribution law ahead of the face, three surveys have been set up which correspond with the layouts: (1) in the upper top coal layer (away 19m from the floor); (2) in the middle top coal layer (away 10m from the floor); (3) in the lower top coal layer (interface between cutting and caving height). The statistical results of the pressure variation during and after the appearance of periodic pressure are outlined in the following figures:

Figure 5 represents the stress distribution at different positions in top coal during the appearance of periodic pressure. Following the face advancement, the concentrated stress zone is constantly moving forward from the coal face. When the cutting/caving ratio is $1: 4.55$, the stress in front of the face at the lower top coal layer reaches the peak value of $20.76 \mathrm{MPa}$ and is away $9.4 \mathrm{~m}$ from the face. For the middle top coal layer, the peak stress is away $6.4 \mathrm{~m}$ with the peak value of $21.45 \mathrm{MPa}$. 


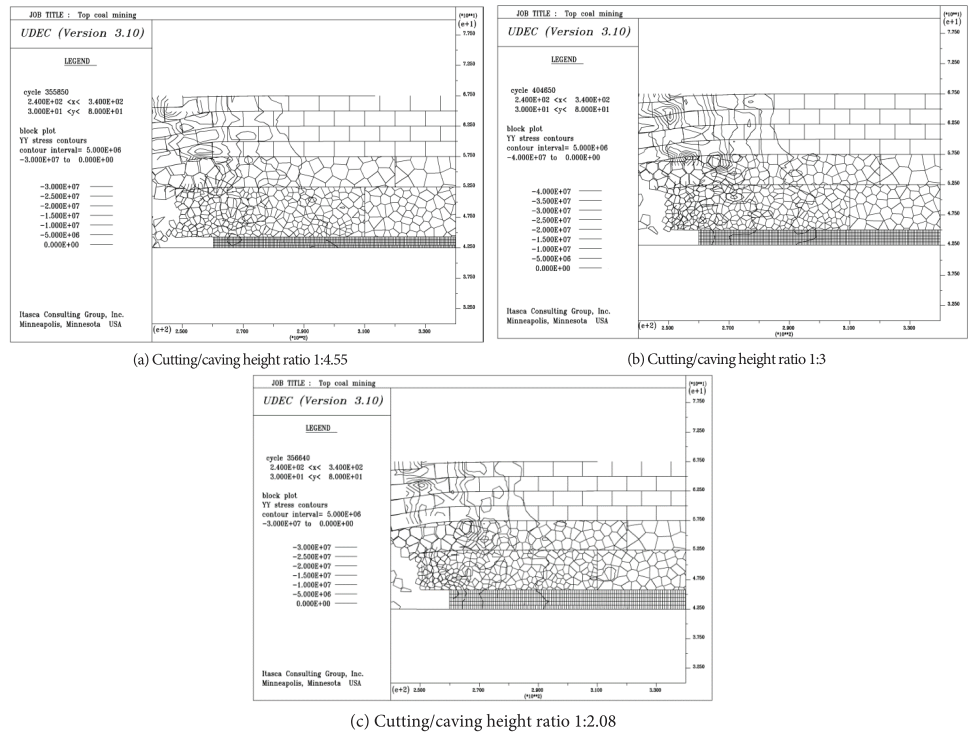

Fig. 4. Stress distribution in front of the face after the appearance of periodic pressure Rys. 4. Rozkład naprężeń przed ścianą po pojawieniu się okresowego ciśnienia

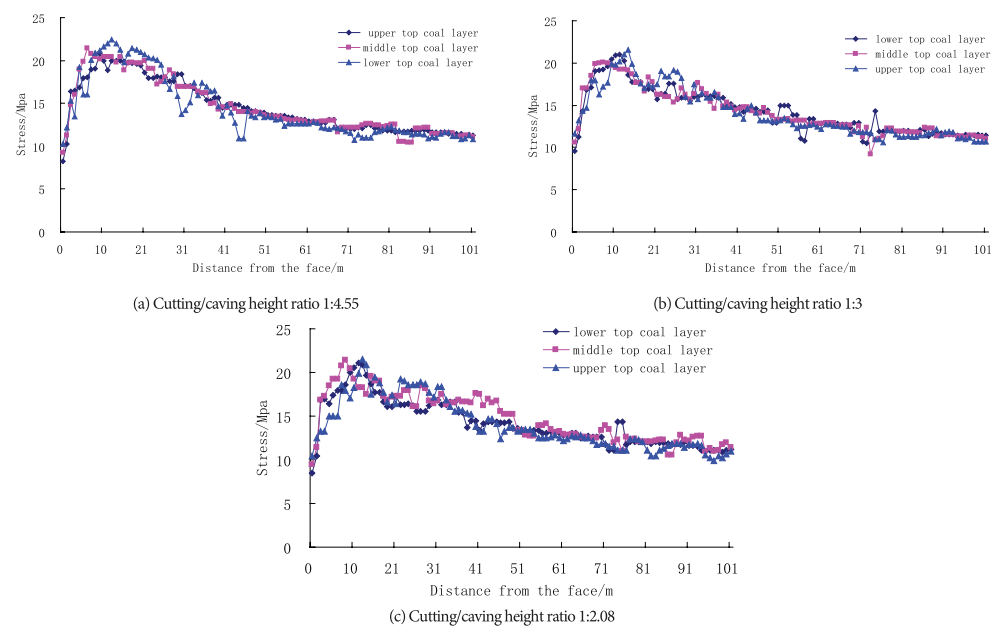

Fig. 5. Graph of stress distribution in front of the face during the appearance of periodic pressure Rys. 5. Wykres rozkładu naprężeń przed ścianą podczas pojawiania się okresowego ciśnienia
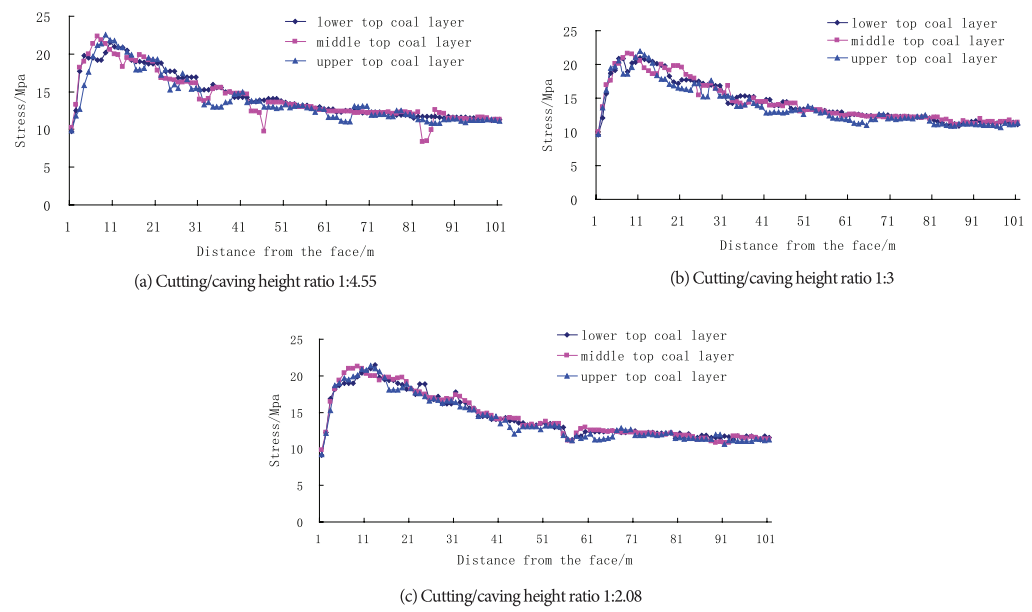

Fig. 8. Graph of stress distribution in front of the face after the appearance of periodic pressure Rys. 8. Rozkład naprężeń przed ścianą po pojawieniu się okresowego ciśnienia 


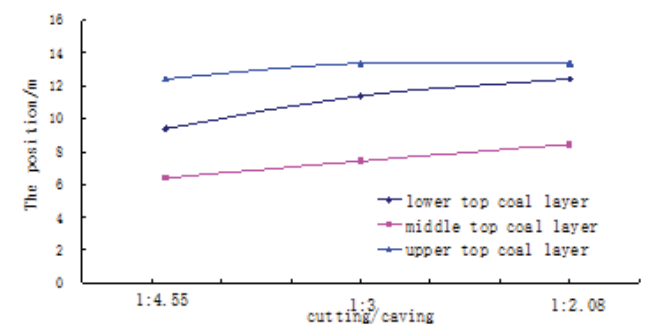

Fig. 6. Change of front peak stress position during the periodic pressure

Rys. 6. Zmiana położenia maksymalnego naprężenia przed ścianą podczas okresowego ciśnienia

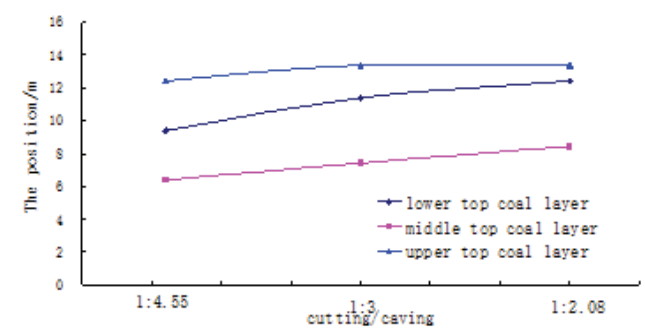

Fig. 7. Change of front peak stress value during the periodic pressure

Rys. 7. Zmiana wartości maksymalnego naprężenia przed ścianą podczas okresowego ciśnienia

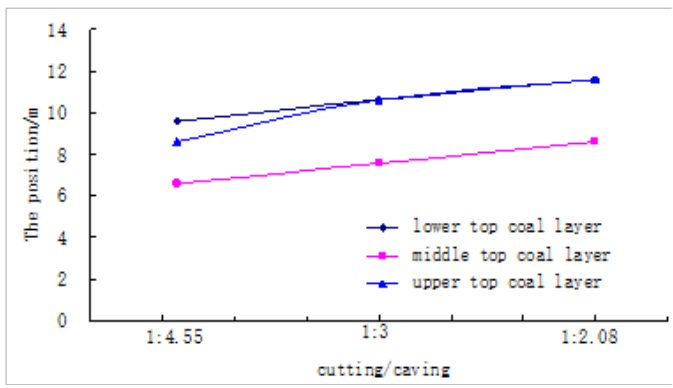

Fig. 9. Change of front peak stress position after the appearance of periodic pressure Rys. 9. Zmiana położenia maksymalnego naprężenia po pojawieniu się okresowego ciśnienia

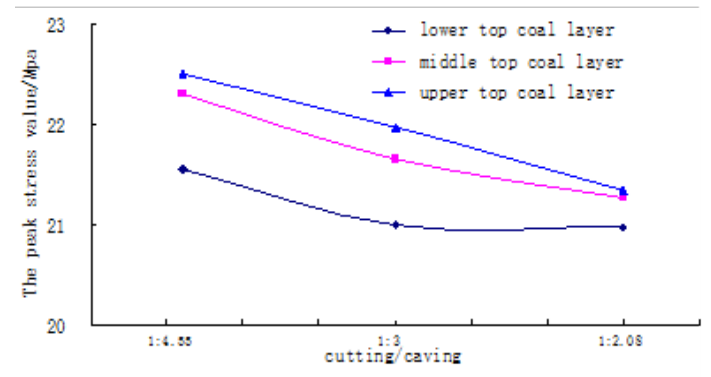

Fig. 10. Change of front peak stress value after the appearance of periodic pressure

Rys. 10. Zmiana wartości maksymalnego naprężenia przed ścianą po pojawieniu się okresowego ciśnienia

The position is away $12.4 \mathrm{~m}$, and the peak value is $22.46 \mathrm{MPa}$ for the upper top coal layer. When the cutting/caving ratio is $1: 3$, the respective values are $11.4 \mathrm{~m}$ and $21.01 \mathrm{MPa}$ (for the lower layer); $7.4 \mathrm{~m}$ and $21.40 \mathrm{MPa}$ (for the middle layer); $13.4 \mathrm{~m}$ and $21.6 \mathrm{MPa}$ (for the upper layer). When the cutting/ caving ratio is $1: 2.08$, the respective values are $12.4 \mathrm{~m}$ and $21.13 \mathrm{MPa}$ (for the lower layer); $8.4 \mathrm{~m}$ and $21.39 \mathrm{MPa}$ (for middle layer); $12.4 \mathrm{~m}$ and $21.52 \mathrm{MPa}$ (for the upper layer).

Figure 6 and Figure 7 illustrate the changes in the position and the peak stress value during the periodic pressure. It is shown that when extracting the extra-thick seam if the cutting/caving ratio varies, the position and value of peak stress will significantly change. For the lower layer and upper layer of top coal, the peak stress positions are relatively far from the coal face, whereas the peak stress point for the middle layer is close to the coal face. The reason is that while the upper layer stands the load of overlying layers, the lower layer is affected by the extraction of the cutting process. This leads to the increase of the top coal breakage in the plastic deformation zone, decreasing the top coal strength and finally, advancing 
the front peak stress further. With the high ratio of cutting/ caving height, the peak stress values in different layers vary significantly, whereas the smaller amplitude of value variation is witnessed with the low ratio of cutting/caving. At a specific cutting/caving height ratio, such amplitude also increases with a certain value.

Figure 8 shows the stress distribution at different positions at top coal layers after the appearance of periodic pressure. Depending on the face advance, the concentrated stress zone is constantly moving forward from the coal face. When the cutting/caving ratio is $1: 4.55$, the stress in front of the face at the lower top coal layer is away $9.6 \mathrm{~m}$ from the face and reaches the peak value of $21.56 \mathrm{MPa}$. For the middle top coal layer, the peak stress is away $6.6 \mathrm{~m}$ from the face with the value of $22.31 \mathrm{MPa}$. The peak stress position is away $8.6 \mathrm{~m}$ and the value is $22.51 \mathrm{MPa}$ for the upper top coal layer. When the cutting/caving ratio is $1: 3$, the respective values are $10.6 \mathrm{~m}$ and $21.00 \mathrm{MPa}$ (for the lower layer); $7.6 \mathrm{~m}$ and $21.66 \mathrm{MPa}$ (for the middle layer); $10.6 \mathrm{~m}$ and $21.98 \mathrm{MPa}$ (for the upper layer) When the cutting/caving ratio is $1: 2.08$, the respective values are $11.6 \mathrm{~m}$ and $20.98 \mathrm{MPa}$ (for the lower layer); $8.6 \mathrm{~m}$ and $21.27 \mathrm{MPa}$ (for middle layer); $11.6 \mathrm{~m}$ and $21.35 \mathrm{MPa}$ (for the upper layer).

Figure 9 and Figure 10 illustrate the changes in the position and the peak stress value at the top coal after the appearance of periodic pressure. It can be seen that when extracting the extra-thick seam, the peak stresses during and after the appearance of periodic pressure are relatively the same while their positions show a certain difference. For the lower and upper top coal layer, the peak stress positions are relatively far from the coal face, whereas the peak stress for the middle one is close to the coal face. Compared to the case of during the periodic pressure, the stress values ahead of the face with and without the effect of main roof rock show little variation. The elements are similar to that during the period of periodic pressure occurring.

By examination of stress distribution at various layers top coal during and after the appearance of periodic pressure, following results are outlined. If the cutting/caving height ratio drops, the peak stress positions of different layers move further from the coal face. During the periodic pressure, the position of abutment stress changes significantly. Specifically, the abutment stress positions of the upper layer and lower layer in top coal are far away from the coal face, whereas such position of the middle layer is quite close to the face. It is ex- plained that the upper and lower layers have partly absorbed the overlying load, which diminishes the destruction in the elastic deformation zone at the middle layer. At the same time, the ratio of cutting/caving has also affected the stress values in front of the face. When the ratio climbs, the stress values will vary the considerable amplitude, whereas such amplitude is less variation if the ratio decreases.

\section{Conclusion}

During and after the appearance of periodic pressure, the failure behaviours of top coal are not the same. In the time of periodic pressure occurring, the top coal is broken mainly due to deformation movement of a main roof rock mass. After the periodic pressure occurs, the compression of entire roof rock mass majorly causes the top coal failure. If the ratio of cutting to caving drops, the stress distribution in the top coal will change. In the time of periodic pressure occurring, the reduction of cutting to caving ratio is beneficial to the top coal breakage and top coal recovery. After the occurrence of periodic pressure, the effect of cutting to caving ratio on face stability is significant in which the drop of ratio leads to the face instability.

For the extraction of extra-thick coal seam, depending on the reduction of cutting/caving ratio, the front peak stresses in different layers also increase. In the time the periodic pressure occurring, the locations of peak stress also show the difference, being far away from the coal face in the upper and lower layer while being relatively close to the face in the middle layer.

The ratio of cutting to caving height has a certain effect on the peak stress value in front of the face at various top coal layers. If such ratio is relatively high, the peak stress values increase from the lower to the upper layers. Conversely, if the ratio decreases, the peak stress values also drop. Therefore, the adjustment of cutting/caving height ratio will adjust the stress distribution, which enables to control the top coal caving ability and face stability.

\section{Acknowledgement}

This research is funded by Hanoi University of Mining and Geology (HUMG) through Project T20-12. The State Key Laboratory of Coal Resources and Mine Safety of China University of Mining and Technology is thanked for providing field measurement data. 


\section{Literatura - References}

1. G.S.P. SINGH, U.K SINGH. A numerical modeling approach for assessment of progressive caving of strata and performance of hydraulic powered support in longwall workings. Computers and Geotechnics 36 (2009) 1142-1156

2. Huang Bingxiang, Li Hongtao, Liu Changyou, Xing Shijun, Xue .Rational cutting height for large cutting height fully mechanized top-coal caving. Mining Science and Technology (China) 21 (2011) 457-462.

3. Humphries P, Poulsen B, Sliva R. Geological assessment and numerical modelling of longwall top-coal caving for broad meadow and wards well. CSIRO report, P2007/102; 2007.

4. Jiachen Wang, Shengli Yang, Yang Li, Like Wei, Haochao Liu. Caving mechanisms of loose top-coal in longwall topcoal .caving mining method. International Journal of Rock Mechanics \& Mining Sciences 71 (2014) 160-170.

5. Jiachen Wang, Jinwang Zhang, Zhaolong Li. A new research system for caving mechanism analysis and its application to sublevel top-coal caving mining. International Journal of Rock Mechanics \& Mining Sciences 88 (2016) 273-285

6. Le, T. D., Oh, J., Hebblewhite, B., Zhang, C. \& Mitra, R. 2018. A discontinuum modelling approach for investigation of Longwall Top Coal Caving mechanisms. International Journal of Rock Mechanics and Mining Sciences, 106, 84-95.

7. N.E. Yasitli, B. Unver. 3D numerical modeling of longwall mining with top-coal caving. International Journal of Rock Mechanics \& Mining Sciences 42 (2005), 219-235. https://doi.org/10.1016/j.ijrmms.2004.08.007Get rights and content.

8. Wang Jiachen. China caving technology and its deep-rooted problems of development. Coal Sci Technol 2005;33(1):14-7

9. https://books.google.com.vn/books?hl=vi\&lr=\&id=ywSiDwAAQBAJ\&oi=fnd\&pg=PA260\&dq=Study+on+controlling+parameters+and+technological+optimization+of+Strip+Longwall+Top+Coal+Caving+in+thick+coal+seams\&ots=S9ml5ax80Y\&sig=_cQV2bTGNOgt9jpmiCnUHVzZQb8\&redir_esc=y\#v=onepage\&q\&f=false

10. https://www.mdpi.com/2071-1050/10/3/700\#cite

11. http://en.cnki.com.cn/Article_en/CJFDTotal-KYYK201502002.htm

12. https://onlinelibrary.wiley.com/doi/full/10.1002/ese3.660

13. http://www.ejge.com/2014/Ppr2014.883ma.pdf

\section{Badanie nad rozkładem naprężeń przed ściana gdy stosunek urabiania do odzyskania zmienia się w eksploatacji dtugich ścian przy bardzo grubych pokładach \\ Przy bardzo grubych pokładach, eksploatacja $z$ duża wysokością to nowy kierunek badań w technologii zawału stropu węla. Ze względu na grubość warstwy stropu węglowego i zwiększona wysokość urabiania prowadzi do zmiany stosunku urabiania do odzys- kania, co również zmienia regułę zapalenia skat stropowych i zmienia stan rozkładu naprężeń wokót ściany. W artykule, przedst- awiono wyniki analizy wplywu stosunku urabiania do uzyskania opierając się na prawie rozkładu obciążenia przed ściana. Analiza ta została oparta na warunkach geologicznych kopalni 8102 TaSan-DaTong wykorzystujac model numeryczny UDEC2D. Wyniki badań pokazują, że wraz ze spadkiem stosunku urabiania do odzyskania, oznacza to wzrost wysokości urabiania, położenie maksy- malnego naprężenia jest daleko od ściany, maksymalna wartość naprężeń znacznie spada, zniszczenie plastyczne przed ściana $i$ stropem gwałtownie rośnie, zwiększa się strefa odkształcenia plastycznego. Dlatego zmiana stosunku urabiania do odzyskania może zmienić stan rozkładu ciśnienia stropowego, co jest korzystne dla procesu niszczenia stropu i kontrolowania stabilności ściany.}

Słowa kluczowe: bardzo gruby pokład, duża wysokość urabiania, stosunek wysokości urabiania/ odzyskania, rozkład naprężeń 